・研究报告・

\title{
三江源国家公园功能分区与目标管理
}

\author{
付梦娣 ${ }^{1}$ 田俊量 $^{2}$ 朱彦鹏 $^{1}$ 田 瑜 $^{1}$ 赵志平 $^{1}$ 李俊生 $^{1^{*}}$ \\ 1 (中国环境科学研究院生物多样性研究中心, 北京 100012) \\ 2 (三江源国家公园管理局，西宁 810007)
}

\begin{abstract}
摘要: 功能分区是国家公园总体规划和科学管理的重要环节。本研究以三江源国家公园黄河源园区为研究对象, 在综合分析区域生态环境基本特征的基础上, 选择生态系统服务、重要物种潜在生境、生态敏感性、生态压力4 大类13项评价指标, 构建了国家公园功能分区评价指标体系, 运用层次分析法(AHP)和专家打分法, 结合管控目 标需求，将黄河源园区划分为核心保育区、生态保育修复区、传统利用区、居住和游鳃服务区 4 个功能区，保护程 度依次降低, 利用程度及公众可进入性依次增强。该功能分区不仅可为三江源国家公园合理规划打下理论基础, 同时也对同类型的国家公园具有可借鉴性。
\end{abstract}

关键词: 国家公园; 三江源; 功能分区; 指标体系; 管控措施

\section{Identification of functional zones and methods of target management in Sanjiangyuan National Park}

\author{
Mengdi Fu' ${ }^{1}$, Junliang Tian ${ }^{1}$, Yanpeng Zhu ${ }^{1}$, Yu Tian ${ }^{1}$, Zhiping Zhao, Junsheng Li $^{1 *}$ \\ 1 Biodiversity Research Center, Chinese Research Academy of Environmental Sciences, Beijing 100012 \\ 2 Three-River-Source National Park Service, Xining 810007
}

\begin{abstract}
Functional zones are the key link for the master planning and scientific management of national parks. We established an evaluation index system to comprehensively analyze regional ecological and environmental features in our study area, the source region of the Yellow River in the Sanjiangyuan National Park. The evaluation index system contains 13 evaluation indices, which include ecosystem services, potential habitat for key species, ecological sensitivity, and ecological pressure classes. By using the Analytic Hierarchy Process (AHP) and experts marking methods and combining the requirements of management and control measures, the study area was divided into four primary functional zones, including a core reserve area, ecological restoration area, traditional utilization area, and residential and recreational service area. The protection gradation for each zone is reduced in turn, and the gradation of utilization and public accessibility is enhanced. This functional zones method laid a solid foundation for the effective planning of Sanjiangyuan National Park, while at the same time, our study provides new insight into the functional zones of national parks.
\end{abstract}

Key words: national park; Sanjiangyuan; functional zone; index system; control measures

建设国家公园是一种严格保护并合理利用自 然文化资源的可持续发展理念和举措(陈耀华等, 2014)。党的十八届三中全会首次明确提出建立国家 公园体制。为有效推动国家公园体制建设, 国家发 展改革委员会等13部委共同印发《建立国家公园体
制试点方案》, 选择在青海省开展国家公园体制试 点。青海三江源地区是国家重要生态安全屏障, 也 是我国重要的淡水资源供给地和高原生物多样性 最集中的地区, 生态系统保持着较高的原始性和完 整性，并保存着丰富的传统民族文化资源。但同时，

收稿日期: 2016-04-06; 接受日期: 2016-09-29

基金项目: 国家自然科学基金(31300458)和环境保护部业务经费“国家公园”项目

* 通讯作者 Author for correspondence. E-mail: lijsh@craes.org.cn 
三江源地区生态环境脆弱, 对气候变化敏感, 一旦 受到较大干扰, 生态系统服务功能退化, 将关系到 全国的生态安全和中华民族的长远发展。有鉴于此, 在三江源地区开展国家公园试点工作, 加强对三江 源地区生态系统完整性、原始性的保护, 探索建立 国家公园制度, 统筹生态保护和区域经济社会的全 面发展显得尤为重要。

功能分区是国家公园总体规划中必不可少的 核心内容, 它规定了国家公园保护和利用的具体空 间和管控要求。黄丽玲等(2007)归纳总结了国外自 然保护地分区模式, 呼延佼奇等(2014)分析了我国 自然保护地功能区划中存在的难点与问题, 发现目 前各国的国家公园均有独立的功能分区体系, 大体 存在主观性较强、概念不清、操作性差等诸多问题。 如何提高功能分区的科学性, 建立功能明确、优势 互补的发展格局, 建立国家公园开发保护制度, 从 而严格按照功能分区定位保护发展, 值得研究讨 论。本文以三江源国家公园黄河源园区为例, 建立 了功能分区评价指标体系, 研究生态系统服务、重 要物种潜在生境、生态敏感性、生态压力及其空间 分布特征, 以期为国家公园实行分区目标管理提供 参考。

\section{1 研究区概况}

黄河源园区位于青海省果洛州玛多县境内, 面 积1.91万 $\mathrm{km}^{2}$, 占玛多县总面积的 $78.01 \%$ 。地势自西 北向东南倾斜, 平均海拔在 $4,400 \mathrm{~m}$ 左右, 年平均气 温 $-4^{\circ} \mathrm{C}$, 年均降水量 $303.9 \mathrm{~mm}$, 年蒸发量为 $1,374.6$ $\mathrm{mm}$, 年均相对湿度38\%, 属高寒草原气候。园区内 河流纵横, 黄河流经约 $408 \mathrm{~km}$, 主要一级支流有勒 那曲、麻石加、东曲、多曲和白玛曲等; 湖泊星罗 棋布, 主要有扎陵湖、鄂陵湖、尔拉拉错、岗纳格 玛错等。草地类型以高寒草甸为主, 分布广、面积 大、区系成分简单，以小嵩草(Kobresia pygmaea)、 禾叶嵩草 $(K$. graminifolia $)$ 和矮生嵩草 $(K$. humilis $)$ 等 为优势种。国家重点保护动物有69种, 其家一级保 护动物有雪豹 (Panthera uncia)、白唇鹿 (Cervus albirostris)、藏野驴(Equus kiang)、野牦牛 (Bos mutus)、黑鹳(Ciconia nigra)、黑颈鹤(Grus nigricollis)、金雕(Aquila chrysaetos)、胡而鹑(Gypaetus barbatus)等 9 种, 国家二级重点保护动物 17 种, 省级
保护动物15种。

\section{2 研究方法}

\section{1 数据来源}

数据主要包括: (1)土地利用数据。以遥感影像 作为基本信息源, 结合土地利用现状图、 $30 \mathrm{~m} \times 30 \mathrm{~m}$ 分辨率的数字高程模型(DEM)以及野外实测的地物 光谱数据, 采用人工交互解译的方法提取土地利用 信息，经过精度验证及成果修订后形成玛多县土地 利用矢量数据。(2)气候数据。来源于中国气象局数 据共享中心, 包括日平均温度、相对湿度、降水量 和日照时数等。其中, 降水量的空间分布格局通过 ANUSPLIN插值软件(Hutchinson \& Xu，2013)将研 究区及周边气象站点的降水量观测值进行插值获 得，空间分辨率为 $1 \mathrm{~km} \times 1 \mathrm{~km}$; 各气象站点的潜在 蒸散 $\left(\mathrm{ET}_{0}\right)$ 采用联合国粮农组织(FAO)1998年对 Penman-Monteith模型修订后的版本 (Allan et al, 1998)计算获得, 并进一步借助ANUSPLIN插值软 件得到其空间分布格局，空间分辨率为 $1 \mathrm{~km} \times 1$ $\mathrm{km}$ 。(3)土壤数据。通过对 $1: 100$ 万土壤空间属性数 据栅格化获得。(4) NPP (净初级生产力)。采用周广 胜等(1998)的自然植被NPP模型得到。(5)人口及牲 畜数量。由玛多县统计年鉴获得。(6)重要物种分布 点数据。来源于中国科学院西北高原生物研究所开 展的玛多县陆生哺乳动物资源调查项目。

\section{2 评价指标体系的构建}

建立国家公园功能分区指标体系是进行功能 区划的重要依据, 直接影响分区过程的科学性和分 区结果的合理性。本次研究在总结前人研究成果的 基础上(王维正，2000; Zafar，2011; Nandy et al, 2015), 提出三江源国家公园黄河源园区功能分区 指标体系(表1)。以自然环境因素为主，综合考虑人 类活动因素, 兼顾指标的重要性、系统性和可获得 性, 选取了13项指标对研究区的生态系统服务、重 要物种潜在生境、生态敏感性和生态压力进行综合 评价。

生态系统服务评价有助于确定生态保护的重 要区域, 可为生态功能定位以及生态环境的建设和 保护提供科学依据。本研究选取了固碳、水源涵养、 土壤保持 3 个主要的生态系统服务功能指标进行评 价(赖敏等, 2013)。 
表1 三江源国家公园功能分区评价指标体系

Table 1 Evaluation index system on functional zones of the Sanjiangyuan National Park

\begin{tabular}{|c|c|c|c|}
\hline 指标类 & 权重 & 指标项 & 权重 \\
\hline Category & Weight & Indicator & Weight \\
\hline \multirow[t]{3}{*}{ 生态系统服务 Ecosystem services } & \multirow[t]{3}{*}{0.35} & 固碳 Carbon sequestration & 0.18 \\
\hline & & 水源涵养 Water conservation & 0.51 \\
\hline & & 土壤保持 Soil conservation & 0.31 \\
\hline \multirow{3}{*}{$\begin{array}{l}\text { 重要物种潜在生境 Potential habitat of } \\
\text { important species }\end{array}$} & \multirow[t]{3}{*}{0.30} & 有蹄类潜在分布 Potential distribution of ungulates & 0.47 \\
\hline & & 鸟类潜在分布 Potential distribution of birds & 0.37 \\
\hline & & 鱼类潜在分布 Potential distribution of fish & 0.16 \\
\hline \multirow[t]{5}{*}{ 生态敏感性 Ecological sensitivity } & \multirow[t]{5}{*}{0.20} & 植被覆盖度 Vegetation coverage & 0.36 \\
\hline & & 河流湖泊 Rivers and lakes & 0.29 \\
\hline & & 地形地貌 Topography & 0.14 \\
\hline & & 土壤侵蚀强度 Soil erosion intensity & 0.12 \\
\hline & & 气候变化指数 Climatic change index & 0.09 \\
\hline \multirow[t]{2}{*}{ 生态压力 Ecological pressure } & \multirow[t]{2}{*}{0.15} & 人口密度 Population density & 0.50 \\
\hline & & 牲畜密度 Livestock density & 0.50 \\
\hline
\end{tabular}

三江源地区拥有大量国家级重点保护动物, 是 我国野生动物保护的重点区域, 明确物种生境空间 分布格局对制定合理有效的保护措施亦十分重要。 园区兽类、鸟类数量巨大，根据野生物种的重要性 篮选了 14 个物种、 3 个类群进行分析，其中包括有蹄 类 8 种、鸟类 4 种、鱼类 2 种。利用物种分布模型 Maxent针对重要物种的潜在分布进行模拟(王维等, 2010; 齐增湘等, 2011), 将模拟得到的物种数据进 行空间插值, 得到每个物种的潜在分布等级图。

生态敏感性是生态系统受到多因子共同作用 而呈现出的抗干扰能力。敏感性高的地区, 生态系 统容易受损, 是生态环境保护和恢复建设的重点, 也是人为活动受限或禁止的地区。本研究选取植被 覆盖度、河流湖泊、地形地貌、土壤侵蚀强度和气 候变化指数 5 个指标对园区生态敏感性进行综合评 价(韦晶等, 2015), 其中气候变化指数反映该地区应 对气候变化的能力和对气候变化的敏感性(吴浩等, 2012)。

生态压力主要是指生态系统受到外界扰动的 压力, 三江源地区主要表现为人口活动和草原载畜 量压力, 这里分别用人口密度和牲畜密度表示。

\section{3 评价方法}

首先, 为便于不同评价指标进行空间叠加运 算, 借助GIS技术将各指标图层统一到同一坐标系 和投影系统下, 并将各指标图层栅格(grid)大小统 一为 $30 \mathrm{~m} \times 30 \mathrm{~m}$ 。其次, 将各评价指标自身所对应 的属性数据按照生态重要性的程度, 依 4 个层次分
级赋值(表2)。第三, 结合层次分析法(analytic hierarchy process)和专家打分法确定指标体系中各个指 标的权重(邓雪等, 2012)。最后, 采用综合指数法(厉 彦玲等, 2005)对各评价指标分级赋值后进行加权叠 加, 并将评价结果分为4级, 即一般重要区、较重要 区、重要区和极重要区。

\section{3 结果}

\section{1 生态特征分析}

通过建立国家公园功能分区评价指标体系(表 1), 对黄河源园区的生态特征进行评价。黄河源园 区生态系统服务空间分布规律明显(图1a), 由东南 部山区向西北部黄河谷地逐渐降低。巴颜喀拉山北 麓冰川雪山、岗纳格玛错、贺陆峡里卡也玛一带生 态系统服务重要性最高, 该区保存有原始的高寒湿 地生态系统, 年均降雨量高, 植被覆盖度较高, 是 黄河源区水源涵养的极重要区域。

由图1b所示, 园区南部为野生动物类型最多的 区域, 主要分布有藏羚羊(Pantholops hodgsonii)、野 牦牛、雪豹、藏野驴、棕熊(Ursus arctos)及黑颈鹤 等野生动物, 种类多、种群大; 中部也分布有多种 野生动物, 其主要生境为扎陵湖和鄂陵湖两大淡水 湖泊, 由于中部是黄河源区的典型湖泊群和沼泽的 分布区域，因此是鸟类和鱼类的主要分布区域，且 珍稀鸟类多、数量大, 水生生物资源丰富。

黄河源园区生态系统敏感程度高(图1c), 其中 以重度敏感为主, 且集中分布在扎陵湖、鄂陵湖和 
表2 三江源国家公园功能分区评价指标分级

Table 2 Classification of evaluation indices on functional zones of the Sanjiangyuan National Park

\begin{tabular}{|c|c|c|c|c|}
\hline 指标项 & 一般 & 较重要 & 重要 & 极重要 \\
\hline Indicator & General & Relatively important & Important & Very important \\
\hline 固碳 & $<60$ & $60-120$ & $120-180$ & $>180$ \\
\hline \multicolumn{5}{|l|}{ Carbon sequestration (g_C/m²) } \\
\hline 水源涵养 & $<200$ & $200-300$ & $300-400$ & $>400$ \\
\hline $\begin{array}{l}\text { Water conservation (mm) } \\
\text { 土壤保持 } \\
\text { Soil conservation (t/ha) }\end{array}$ & $0-50$ & $50-200$ & $200-400$ & $>400$ \\
\hline 有蹄类潜在分布 & 不适宜 & 较不适宜 & 适宜 & 最适宜 \\
\hline Potential distribution of ungulates & Unsuitable & Less suitable & Suitable & Most suitable \\
\hline 鸟类潜在分布 ～～～～～～ & 不适宜 & 较不适宜 & 适宜 & 最适宜 \\
\hline Potential distribution of birds & Unsuitable & Less suitable & Suitable & Most suitable \\
\hline 鱼类潜在分布 ～～～～ & 不适宜 & 较不适宜 & 适宜 & 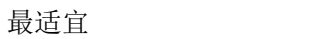 \\
\hline Potential distribution of fish & Unsuitable & Less suitable & Suitable & Most suitable \\
\hline 植被覆盖度 ～～～～～ & $<30$ & $30-45$ & $45-60$ & $>60$ \\
\hline \multicolumn{5}{|l|}{ Vegetation coverage (\%) } \\
\hline 河流湖泊 ～～～～～～～ & 其他区域 & 河流100 m缓冲区 & 河流50 m缓冲区 & 河流、湖泊、湿地 \\
\hline Rivers and lakes & Other regions & River 100 m buffer & River 50 m buffer & Rivers, lakes and wetlands \\
\hline 地形地貌 & - & 冲湖积平原 ～～～～～～～～～ & - & 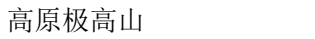 \\
\hline Topography & & Alluvial lacustrine plain & & $\begin{array}{l}\text { Plateau and extremely high } \\
\text { mountains }\end{array}$ \\
\hline 土壤侵蚀强度 & 微度侵蚀 & 轻度侵蚀 & 中度侵蚀 & 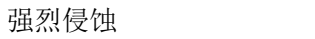 \\
\hline Soil erosion intensity & Mired erosion & Mild erosion & Medium erosion & Strong erosion \\
\hline 气候变化指数 & $<2.5$ & $2.5-3.0$ & $3.0-3.5$ & $>3.5$ \\
\hline \multicolumn{5}{|l|}{ Climatic change index } \\
\hline 人口密度 ～～～～～ & $0-0.25$ & $0.25-0.5$ & $0.5-0.75$ & $0.75-1.0$ \\
\hline \multicolumn{5}{|l|}{ Population density (人/km²) } \\
\hline 牲畜密度 ～～～～～ & $0-15$ & $15-30$ & $30-45$ & $45-60$ \\
\hline \multicolumn{5}{|l|}{ Livestock density (头/ $/ \mathrm{km}^{2}$ ) } \\
\hline 分级赋值 Classification assignment & 1 & 2 & 3 & 4 \\
\hline
\end{tabular}

星星海一带, 占研究区总面积的 $42.45 \%$; 其次为中 度敏感，多为中低盖度草地，所占比例为 $34.22 \%$; 轻度和微度敏感区所占比例分别为 $16.56 \%$ 和 $6.77 \%$, 主要分布在鄂陵湖北部哈拉山、扎陵湖南部、塘格 玛及黄河沿岸。

生态压力度由高至低依次为花石峡镇、黄河乡、 玛查里镇、扎陵湖乡。总体上, 黄河源园区地广人稀, 土地利用以传统畜牧业为主, 产业结构单一, 人类 活动对自然生态的干扰程度相对较低(图1d)。

\section{2 分区方案}

依据不同区域主导生态系统服务功能及生态 保护目标, 统筹考虑未来社区发展、访客体验、环 境教育的主要区域, 遵循完整性、等级性、相似性 与差异性、发生学原则, 将三江源国家公园黄河源 园区划分为 4 个功能区, 分别为核心保育区、生态保 育修复区、传统利用区、居住和游僖服务区(图2)。 核心保育区面积为 $5,488.83 \mathrm{~km}^{2}$, 占公园总面积的 28.74\%, 该区保存有原始的湿地生态系统、草地生 态系统, 是重要的生态系统服务功能区, 主要分布
的代表性珍稀濒危物种有雪豹、藏羚羊、野牦牛、 藏野驴、藏原羚等; 生态保育修复区面积为 $2,788.49$ $\mathrm{km}^{2}$, 占公园总面积的 $14.60 \%$, 该区含有重要并脆弱 的生态系统类型，包括退化草地，以及需要进行湿 地修复、沙化治理、鼠虫害防治等重点生态治理工 程项目实施区域，是生态保护和建设的重点区域;传 统利用区面积为 $10,817.92 \mathrm{~km}^{2}$, 占公园总面积的 $56.65 \%$ ，该区有质量良好的草场，相对丰富的人文 资源，生态状况稳定，可在一定约束条件下利用; 居 住和游息服务区约占公园总面积的 $0.3 \%$, 以开放的、 具有重要宣教意义的自然和人文景观为基础，呈点 线状分布，包括玛查理镇、花石峡镇、黄河乡和扎陵 湖乡19个村城乡规划建设用地、道路和基础设施、 旅游景点和游頽服务规划用地。该区是为满足公园 必要的经济发展和当地居民生活要求而设立的区 域，是生态旅游和特许经营产业发展的支撑基地。

\section{3 管控措施}

结合黄河源园区功能区划, 实行各有侧重的保 护、利用管控策略和补偿、奖补政策。同时，在遵 

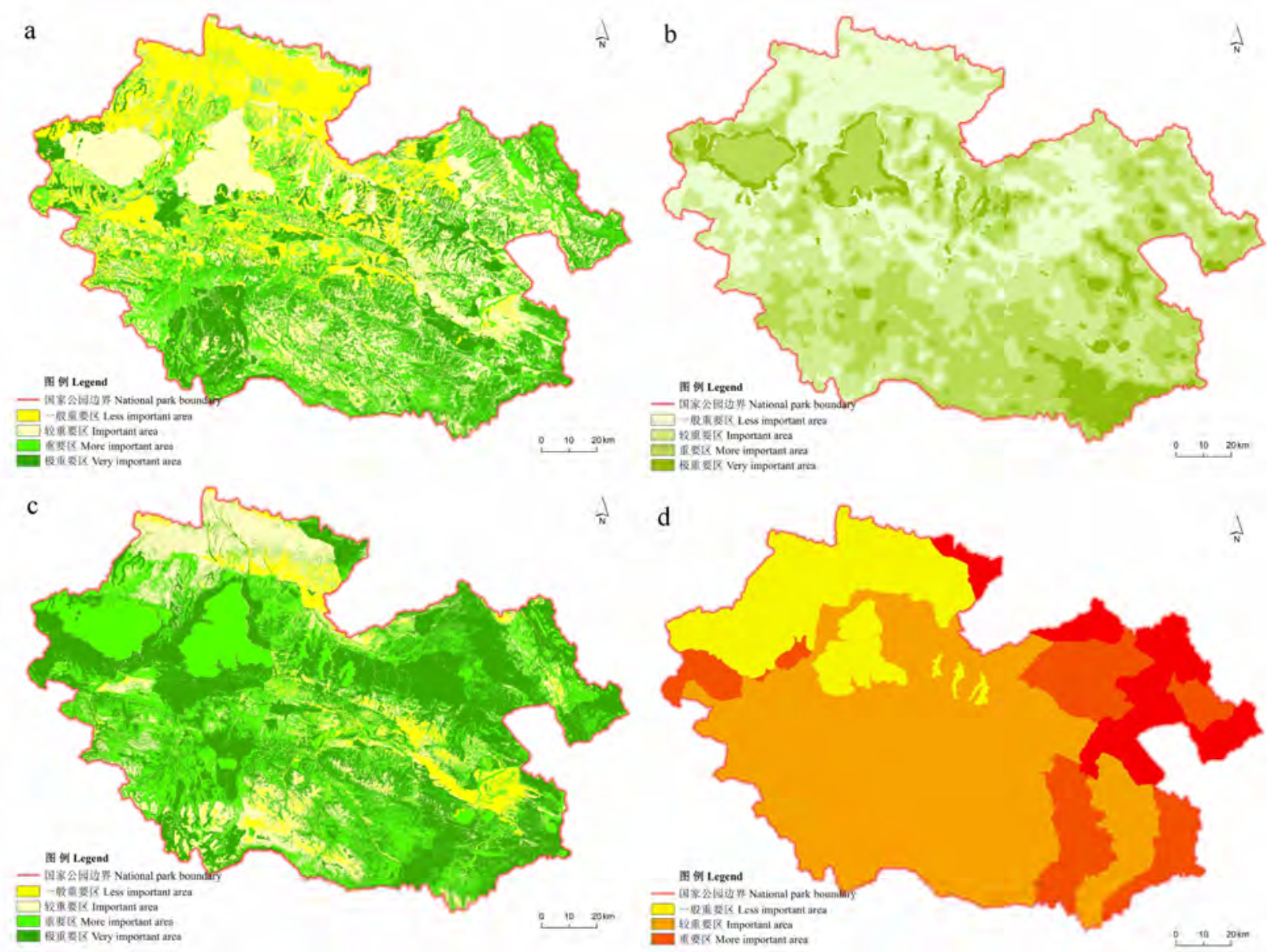

图1 三江源国家公园各指标项的空间分布。(a)生态系统服务; (b)重要物种潜在生境; (c)生态敏感性; (d)生态压力。

Fig. 1 The spatial distribution of each indicator in Sanjiangyuan National Park. (a) Ecosystem service; (b) Potential habitat of important species; (c) Ecological sensitivity; (d) Ecological pressure.

循自然规律的前提下, 通过采取适宜于三江源生态 保护特点的畜牧业生产经营方式和草场利用方式, 科学实现草畜平衡, 有效降低草场退化和沙化程 度。从核心保育区到居住和游喤服务区, 保护程度 逐渐降低, 利用程度及公众可进入性逐渐增强, 各 类功能分区生态特征及管控措施见Box1。

\section{4 讨论与结论}

国家公园具有自然资源保护、科研监测、访客 体验、解说教育、社区发展等多重功能, 采用合适 的分区模式是实现国家公园科学管理、有效提升其 功能的关键。美国国家公园的分区管理经历了一个 不断发展的过程, 由二分法演进至三分法、四分法, 到现今采用的ORRRC分区模式: 高密度游息区、一 般户外游憩区、自然环境区、特殊自然区、原始区、 历史文化遗址等(Dilsaver, 1994; Nationnal Park
Service, 2009), 从而最大化发挥其多重功能。加拿 大国家公园按照生态系统和文化资源的保护要求、 现存和潜在的游客体验机会及影响进行分区, 划分 为特别保护区、荒野区、自然环境区、户外游欯区、 公园服务区(Price, 1983), 从而在有效保护自然生 态环境的同时, 也让国家公园充分发挥其公益性功 能。日本依据保护对象重要程度和可开发利用强度 将国家公园划分为特别保护地区、特别地域(又分为 I级、II级和III级)、普通地域和海中公园地区 $(\mathrm{Xu}$, 2013), 使保护目标与可持续利用界线分明。我国在 国家公园功能分区上的研究起步较晚, 台湾地区按 资源特性与土地利用形态将国家公园划分为生态 保护区、特别景观区、史迹保存区、游唵区和一般 管制区, 以不同措施达成保护与利用功能(陈丹, 2015)。总之, 不同国家的国家公园类型多样, 其自 然地理、社会经济、保护对象各不相同, 其对功能 


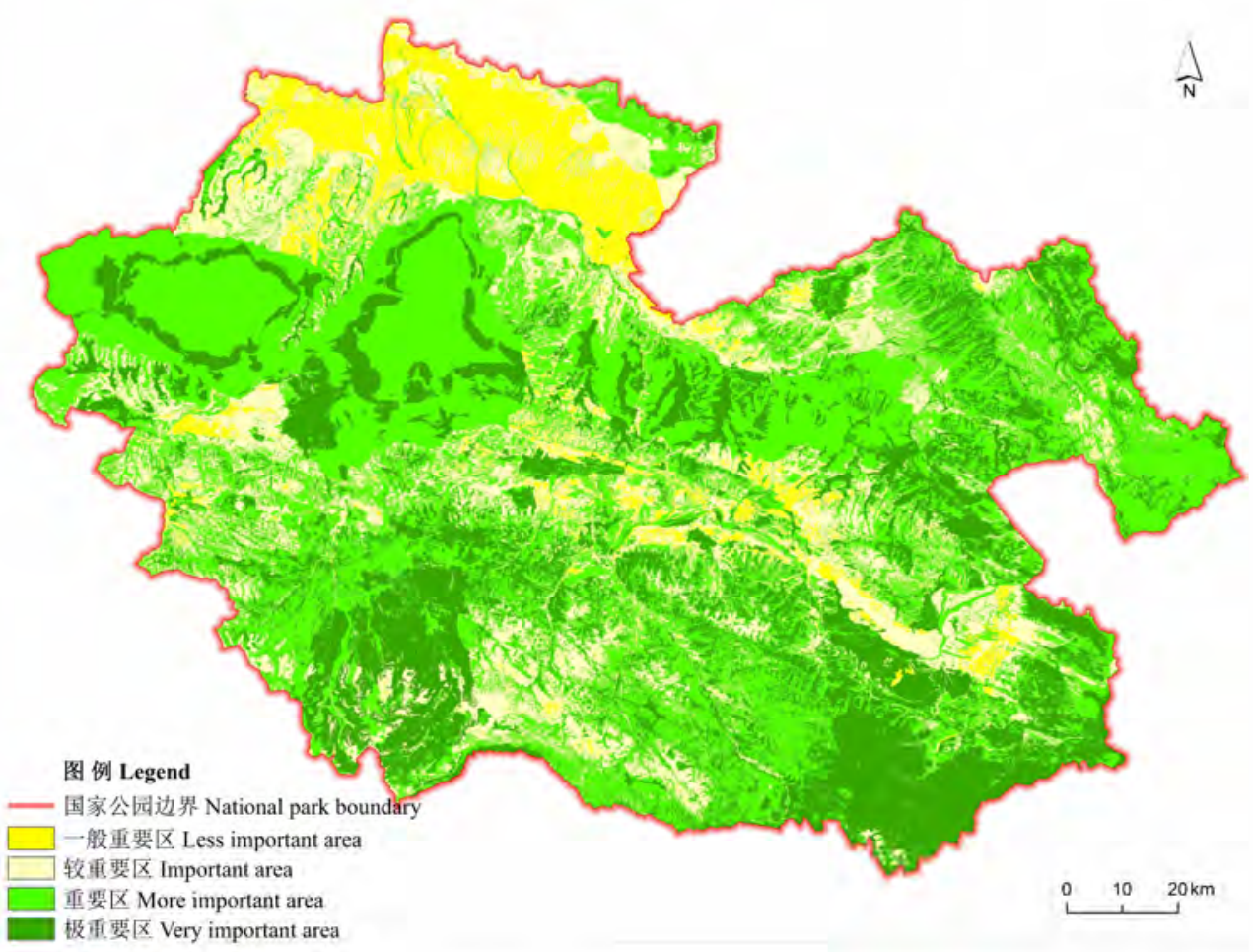

图2 三江源国家公园黄河源园区综合评价

Fig. 2 Comprehensive assessment of the source region of Yellow River of Sanjiangyuan National Park

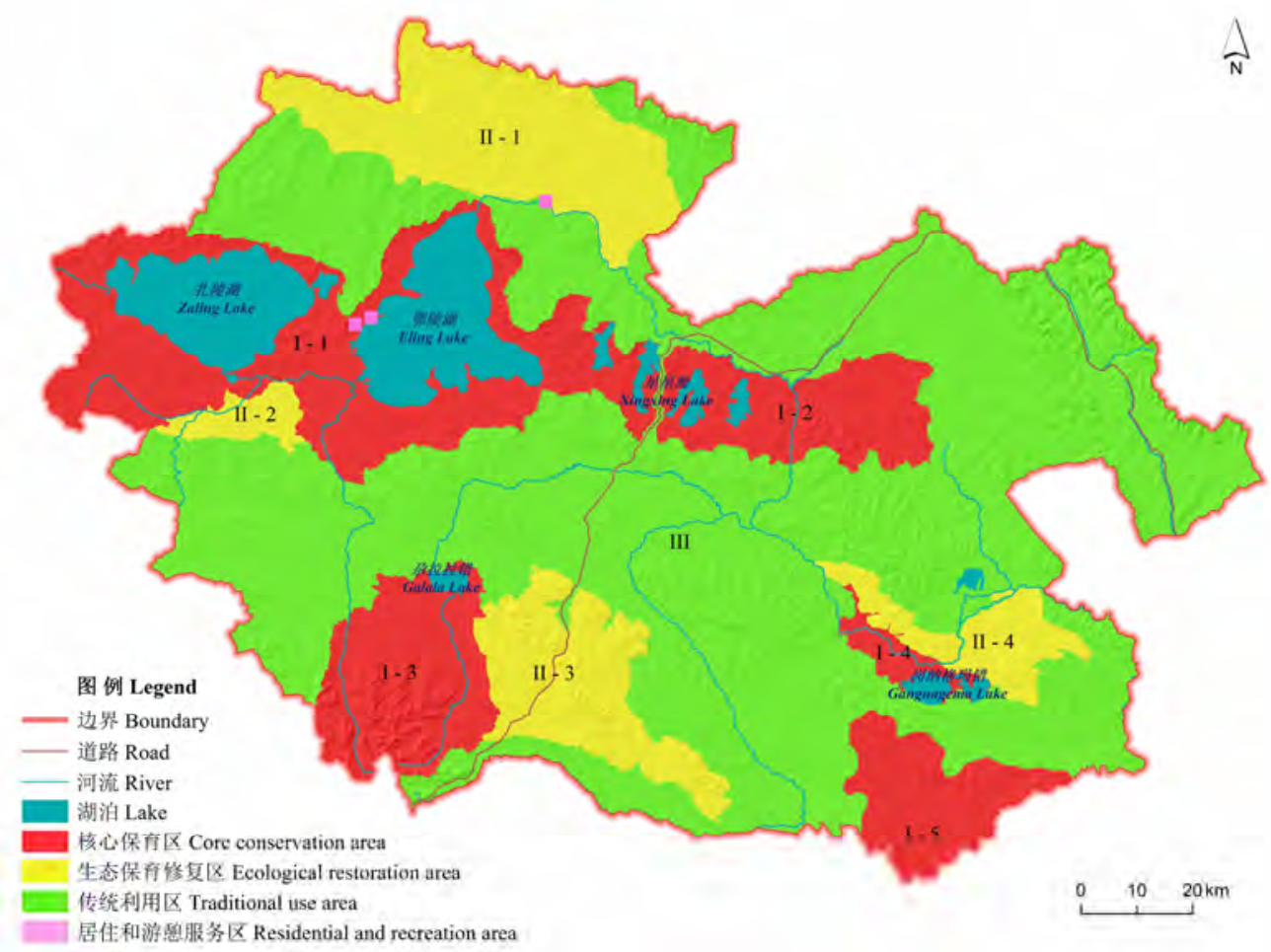

图3 三江源国家公园黄河源园区功能分区(I、II、III、IV为分区编号，同Box 1)

Fig. 3 The functional zones of the source region of Yellow River of the Sanjiangyuan National Park. I, II, III and IV are the partition numbers corresponding to Box 1. 


\section{Box 1 三江源国家公园黄河源园区功能分区、生态特征及其管控措施}

\section{I 核心保育区 $\left(5,488.83 \mathrm{~km}^{2}\right)$}

I-1 扎陵湖-鄂陵湖生态特征: 大面积高原湖泊管理目标: 保护高寒生态系统、珍稀野生动植物 核心保育区湿地，中高覆盖度草地，有 措施要求：对湿地进行封禁保育，执行严格的草畜平衡，执行野生 蹄类、鸟类等重要物种栖息动物保护补偿制度; 在允许的范围内可开展一定的参观游憩，景观 地周边禁止修建与国家公园整体相违背的人工设施和建筑，且游客

I-2 星星海核心 生态特征: 原始的高寒湿地的数量、路线和行为等受园区管理委员会统一管理 保育区 生态系统

I-3 尔拉拉错核心 保育区

生态特征: 巴颜喀拉山水源 涵养功能区

I-4 岗纳格玛错 核心保育区

I-5 贺陆峡里卡也 玛核心保育区

生态特征: 原始的湿地生态管理目标: 保护高寒生态系统、珍稀野生动植物 系统，特有鱼类分布区措施要求：对湿地进行封禁保育，执行严格的草畜平衡，执行野生 动物保护补偿制度

生态特征: 白唇鹿、藏牦牛管理目标: 保护高寒草原草甸生态系统、珍稀野生动植物 等重要物种栖息地 措施要求: 考虑草地承载力和野生动物种群数量, 可开展一定程度 的传统牧业, 执行严格的草畜平衡, 执行野生动物保护补偿制度

\section{II 生态保育修复区 $\left(2,795.45 \mathrm{~km}^{2}\right)$}

II-1 哈拉山保育 修复区

II-2 扎陵湖南保 育修复区

生态特征：退化草地、沙 地、裸岩

生态特征: 低盖度草地、裸管理目标: 对退化草地、湿地及水土流失区修复

II-3 叶合苟南门得 保育修复区

II-4 塘格玛保育 修复区

生态特征: 低盖度草地、裸 管理目标: 对退化草地及水土流失区修复 岩 阶段性禁牧、禁止开发建设项目进入 措施要求: 以自然恢复和人工修复相结合的方式进行修复, 恢复草 地生态系统，阶段性禁牧、禁止开发建设项目进入

管理目标: 对退化草地、沙化地及水土流失区修复

措施要求: 以自然恢复和人工修复相结合的方式进行修复, 恢复草 地生态系统，实施封沙育草、生物治沙等重点生态治理工程项目，

措施要求: 以自然恢复和人工修复相结合的方式进行修复, 恢复草 地生态系统，阶段性禁牧、禁止开发建设项目进入

生态特征: 退化草地、沙地管理目标: 对退化草地、沙化地、“黑土滩”及水土流失区修复 措施要求: 以自然恢复和人工修复相结合的方式进行修复, 恢复草 地生态系统，实施沙化治理、鼠虫害防治等重点生态治理工程项目， 阶段性禁牧、禁止开发建设项目进入

\section{III 传统利用区 $\left(10,810.96 \mathrm{~km}^{2}\right)$}

生态特征: 中低覆盖度草 地，区域生态状况稳定
管理目标: 保护湿地、草原草甸生态系统、珍稀野生动植物, 开展 生态畜牧业

措施要求: 基于草场承载力, 严格执行草畜平衡; 在该区的草地退 化、沙化、黑土滩等区域，以自然恢复为主，通过实施阶段性禁牧， 促进生态系统的良性发展; 在允许的范围内可开展一定的参观游 憩，景观周边禁止修建与国家公园整体相违背的人工设施和建筑， 且游客的数量、路线和行为等受园区管理委员会统一管理

\section{IV 居住和游覣服务区面积}

生态特征: 具有重要宣教 意义的自然和人文景观
管理目标: 社区发展, 访客体验, 环境教育

措施要求：作为园区支撑区域，是人口聚居和集中区域、访客体验 和环境教育的主要区域，保护生态环境，建设必要的、完备的基础 服务设施。 
区划的要求亦不相同, 但大体上都是基于联合国教 科文组织提出的三圈层结构展开。人地关系的紧张 程度决定了各功能区面积分配比例关系。

不同国家针对国家公园功能分区过程亦有着 不同的理论框架, 但内容都包括: 确定保护对象和 目标、资源评估、管理决策和制定监测方案 (Margules \& Pressey, 2000)。

保护对象是国家公园内受保护的生物多样性 特征或要素, 可以是生物特征(物种和群落), 也可 以是作为生物特征替代的环境要素(地质、气候等)。 保护目标的确定是在确定主要保护对象的基础上 权衡多方利益, 最终在平衡保护与可持续利用关系 后确定不同等级的保护目标, 其过程一般采用专家 访谈法(Groves et al, 2002)。

资源评估是国家公园功能区划的重要方法之 一, 主要是通过评估公园内的生物多样性价值、保 护对象的生存力和生态完整性(Anderson, 1999)、生 态脆弱性、气候变化敏感性(Scott et al, 2002)、生态 承载力和威胁因子等, 来确定资源的不同保护等 级, 以此作为重要参考值, 划分不同的功能区。此 外, 历史和人文价值也被作为重要资源的评价内 容, 从而最大可能地保护原有自然文化资源不受 侵害。

管理决策主要是通过功能区区划协调不同保 护目标和管理或参与者之间的相互关系, 达到管理 效能最大化, 其内容涵盖了自然文化资源保护、访 客体验教育和促进社区发展三方面, 多利益群体 (公园管理者、访客、社区居民)参与式预警 (Puhakka \& Saarinen, 2013)、公众参与式地理信息系统 (PPGIS)等(Brown \& Weber, 2011)已逐渐成为规划 管理决策的重要途径。制定国家公园监测方案, 掌 握保护对象的动态, 是完善或修编国家公园功能区 划的重要基础, 已受到国家公园管理者的普遍关 注, 而生态环境监测、生物多样性保护监测、社区 发展监测、游客体验监测等在不同国家成为国家公 园的监测指标以及国家公园功能区划的重要指标。

我国现有的自然保护地类型包括自然保护区、 风景名胜区、森林公园、地质公园、湿地公园等。 自然保护地分区模式多注重自然生态系统, 基本都 采用联合国教科文组织提出的三圈层模式。而国家 公园分区模式在生态保护的前提下, 更加突出人类 在生态系统中的地位, 尤其在其评价指标体系中,
统筹考虑未来社区发展、访客体验、环境教育等人 类活动。黄河源园区内有三江源国家级自然保护区 的扎陵湖一鄂陵湖自然保护分区、星星海自然保护 分区、黄河源国家水利风景区、扎陵湖鄂陵湖花斑 裸鲤和极边扁咽齿鱼国家级水产种质资源保护区、 扎陵湖国际重要湿地和鄂陵湖国际重要湿地, 存在 着各类保护地交叉重叠的问题。三江源国家公园的 建立将重点解决保护地交叉重叠、多头管理、管理 不到位等突出问题, 科学合理的功能分区有助于自 然资源保护和平衡各方利益。

本文借鉴国际经验, 遵循突出保护价值和级 别, 注重保护与持续利用相协调, 结合生态环境实 际状况, 构建了具有三江源特点的国家公园功能分 区评价指标体系, 能够识别出区域生态系统服务重 要区、重要物种潜在生境分布情况以及生态敏感 性、生态压力的空间分布特征，可为国家公园总体 布局与分区管控打下基础; 将生态保护、访客体验、 社区发展三大目标具体深化为各功能区的管控措 施, 形成了具有三江源特色的国家公园管理目标体 系，以期最大限度地保持自然生态系统和自然文化 遗产的完整性与原始性。

\section{参考文献}

Allan RG, Pereira LS, Raes D, Smith M (1998) Crop Evapotranspiration: Guidelines for Computing Crop Water Requirements. Irrigation and Drainage Paper No. 56. FAO, 56.

Anderson MG (1999) Viability and Spatial Assessment of Ecological Communities in the Northern Appalachian Ecoregion. PhD dissertation, University of New Hampshire, Durham.

Brown G, Weber D (2011) Public participation GIS: a new method for national park planning. Landscape and Urban Planning, 102, 1-15.

Chen D (2015) The enlightenment of Taiwan national parks on the construction management of the mainland nature reserves. China Forest Products Industry, 42(5), 58-60. (in Chinese) [陈丹 (2015) 台湾国家公园对大陆自然保护区 建设管理的启示. 林产工业, 42(5), 58-60.]

Chen YH, Huang D, Yan SQ (2014) Discussions on public welfare, state dominance and scientificity of National Park. Scientia Geographica Sinica, 34, 257-264. (in Chinese with English abstract) [陈耀华, 黄丹, 颜思琦 (2014) 论国家 公园的公益性、国家主导性和科学性. 地理科学, 34, 257-264.]

Deng X, Li JM, Zeng HJ, Chen JY, Zhao JF (2012) Research on computation methods of AHP weight vector and its applications. Mathematics in Practice and Theory, 42(7), 
93-100. (in Chinese with English abstract) [邓雪, 李家铭, 曾浩健, 陈俊羊, 赵俊峰 (2012) 层次分析法权重计算方 法分析及其应用研究. 数学的实践与认识, 42(7), 93-100.]

Dilsaver LM (1994) America's National Park System: The Critical Documents. Rowman \& Littlefield, Lanham MD.

Groves CR, Jensen DB, Valutis LL, Redford KH, Shaffer ML, Scott MJ, Baumgartner JV, Higgins JV, Beck MW, Anderson AM (2002) Planning for biodiversity conservation: putting conservation science into practice. BioScience, 52, 499-512.

Huang LL, Zhu Q, Chen T (2007) Comparison of zoning models in protected natural areas overseas and its enlightenment. Tourism Tribune, 22(3), 18-25. (in Chinese with English abstract) [黄丽玲, 朱强, 陈田 (2007) 国外 自然保护地分区模式比较及启示. 旅游学刊, 22(3), 18-25.]

Hutchinson MF, Xu TB (2013) ANUSPLIN version 4.4 User Guide. Centre for Resource and Environmental Studies, The Australian National University, Canberra.

Huyan JQ, Xiao J, Yu BW, Xu WH (2014) Research progress in function zoning of nature reserves in China. Acta Ecologica Sinica, 34, 6391-6396. (in Chinese with English abstract) [呼延佼奇, 肖静, 于博威, 徐卫华 (2014) 我国 自然保护区功能分区研究进展. 生态学报, 34, 63916396.]

Lai M, Wu SH, Dai EF, Yin YH, Zhao DS (2013) The indirect value of ecosystem services in the Three-River Headwaters Region. Journal of Natural Resources, 28, 38-50. (in Chinese with English abstract) [赖敏, 吴绍洪, 戴尔阜, 尹 云鹤, 赵东升 (2013) 三江源区生态系统服务间接使用 价值评估. 自然资源学报, 28, 38-50.]

Li YL, Zhu BL, Wang L, Zhao R (2005) Designing and application of comprehensive index method based on ecological environment quality comprehensive evaluation system. Science of Surveying and Mapping, 30(1), 89-91. (in Chinese with English abstract) [厉彦玲, 朱宝林, 王亮, 赵荣 (2005) 基于综合指数法的生态环境质量综合评价 系统的设计与应用. 测绘科学, 30(1), 89-91.]

Margules CR, Pressey RL (2000) Systematic conservation planning. Nature, 405, 243-253.

Nandy S, Singh C, Das KK, Kingma NC, Kushwaha S (2015) Environmental vulnerability assessment of eco-development zone of Great Himalayan National Park, Himachal Pradesh, India. Ecological Indicators, 57, 182-195.

Nationnal Park Service (2009) General Management Planning Dynamic Sourcebook. https://parkplanning.nps.gov/files/ GMPSourcebook/GMPSourcebook_Dec2009ver2.2.pdf. (accessed on 2016-11-14).

Price MF (1983) Management planning in the sunshine area of Canada's Banff National Park. Parks, 7, 6-10.

Puhakka R, Saarinen J (2013) New role of tourism in national park planning in Finland. Journal of Environment and Development, 22, 411-434.
Qi ZX, Xu WH, Xiong XY, Ouyang ZY, Zheng H, Gan DX (2011) Assessment of potential habitat for Ursus thibetanus in the Qinling Mountains. Biodiversity Science, 19, 343-352. (in Chinese with English abstract) [齐增湘, 徐卫 华, 熊兴耀, 欧阳志云, 郑华, 甘德欣 (2011) 基于 MAXENT模型的秦岭山系黑熊潜在生境评价. 生物多样 性, 19, 343-352.]

Scott D, Malcolm JR, Lemieux C (2002) Climate change and modelled biome representation in Canada's national park system: implications for system planning and park mandates. Global Ecology Biogeography, 11, 475-484.

Wang W, Zhang Z, Jiang Y, Liu XF, Xu C (2010) Assessment of giant panda habitat after the Chengdu earthquake based on habitat suitability. Research of Environmental Sciences, 23, 1128-1135. (in Chinese with English abstract) [王维, 张哲, 江源, 刘孝富, 许超 (2010) 基于生境适宜度的成 都震后大熊猫生境评价. 环境科学研究, 23, 1128-1135.]

Wang WZ (2000) National Parks. China Forestry Publishing House, Beijing. (in Chinese) [王维正 (2000) 国家公园. 中国林业出版社, 北京.]

Wei J, Guo YM, Sun L, Jiang T, Tian XP, Sun GD (2015) Evaluation of ecological environment vulnerability for Sanjiangyuan area. Chinese Journal of Ecology, 34, 19681975. (in Chinese with English abstract) [韦晶, 郭亚敏, 孙 林, 江涛, 田信鹏, 孙光德 (2015) 三江源地区生态环境 脆弱性评价. 生态学杂志, 34, 1968-1975.]

Wu H, Hou W, Qian ZH, Hu JG (2012) The research on the sensitivity of climate change in China in recent 50 years based on composite index. Acta Physica Sinica, 61, 149205. (in Chinese with English abstract) [吴浩, 侯威, 钱忠 华, 胡经国 (2012) 基于气候变化综合指数的中国近50 年来气候变化敏感性研究. 物理学报, 61, 149-205.]

$\mathrm{Xu} \mathrm{H}$ (2013) Evolvement, system and characteristics of national parks in Japan. World Forestry Research, 26(6), 69-74.

Yang PF (2012) Biodiversity monitoring of Meili Snow Mountain National Park. Forest Inventory and Planning, 37(5), 108-111. (in Chinese with English abstract) [杨沛芳 (2012) 梅里雪山国家公园生物多样性监测. 林业调查规 划, 37(5), 108-111.]

Zafar SM, Baig MA, Irfan M (2011) Application of GIS/RS for management zoning of Margallah Hills National Park, Islamabad. International Conference on Environmental Science and Technology, 2, 6-9.

Zhou GS, Zheng YR, Chen SQ, Luo TX (1998) NPP model of natural vegetation and its application in China. Scientia Silvae Sinicae, 34(5), 2-11. (in Chinese with English abstract) [周广胜, 郑元润, 陈四清, 罗天祥 (1998) 自然 植被净第一性生产力模型及其应用. 林业科学, 34(5), 2-11.]

(责任编委: 马克平 责任编辑: 时意专) 